\title{
PERENCANAAN ULANG SISTEM PROTEKSI KEBAKARAN PADA GEDUNG SERBAGUNA TEKMIRA JEND. SUDIRMAN NO. 623 BANDUNG
}

\author{
Ihsan Silahuddin, Tatang Efendi, Mei Sutrisno, Ruth Ester Ambat \\ Jurusan Teknik Sipil Politeknik Negeri BandungJl. Gegerkalong Hilir Ds.Ciwaruga Bandung 40012. \\ E-mail: ihsansilahudinn@gmail.com
}

\begin{abstract}
ABSTRAK
Kebakaran merupakan salah satu bahaya yang sangat merugikan bagi masyarakat oleh sebab itu diperlukan suatu sistem pencegahan kebakaran untuk mengurangi dampak dan kerugian yang diakibatkan oleh kebakaran. Gedung Serbaguna Tekmira ini berdasarkan hasil evaluasi sistem proteksi kebakaran yang telah dilakukan sebelumnya belum memenuhi persyaratan secara penuh sesuai dengan Undang-undang No. 28 tahun 2002 tentang bangunan gedung dan Standar Nasional Indonesia (SNI). Perencanaan ulang sistem proteksi kebakaran gedung Serbaguna Tekmira ini meliputi, perencanaan sistem sprinkler, hydrant gedung, detector kebakaran dan penambahan tangga darurat sebagai jalur evakuasi ketika terjadi kebakaran. Hasil dari perencanaan sistem proteksi kebakaran ini adalah 294 titik sprinkler dengan Wet Pipe System, 16 titik hydrant gedung, 49 titik detector kebakaran dan pembuatan tangga melingkar berbahan baja untuk jalur evakuasi saat terjadi kebakaran dan memerlukan biaya sebesar Rp. 6.089.553.838, -
\end{abstract}

Kata Kunci: sistem proteksi kebakaran, sistem sprinkler, hydrant, detektor kebakaran, tangga darurat.

\section{PENDAHULUAN}

Sesuai dengan persyaratan keandalan bangunan gedung sebagaimana tertuang dalam Undangundang No. 28 tahun 2002 tentang Bangunan Gedung atau lebih dikenal dengan UUBG 2002, khususnya pada paragraf 2 pasal 19 persyaratan yang harus dipenuhi adalah keselamatan terhadap bahaya kebakaran. Untuk memenuhi persyaratan tersebut, bangunan gedung harus menerapkan system proteksi total, yang mencakup proteksi pasif, proteksi aktif dan membentuk manajemen keselamatan terhadap bahaya kebakaran.

Berdasarkan hasil evaluasi awal gedung Serbaguna Temira ini, gedung Serbaguna Tekmira ini belum memiliki system proteksi terhadap kebakaran secara penuh. Pada gedung Serbaguna Tekmira ini tidak terdapat sisten proteksi kebakaran aktif seperti system sprinkler, hydrant gedung dan detector kebakaran. Sehingga perlu dilakukan desain ulang system proteksi kebakaran pada bangunan gedung Serbaguna ini. Adapun beberapa system yang di desain ulang adalah system sprinkler, hydrant gedung, detector kebakaran dan penambahan tangga kebakaran untuk jalur evakuasi sebagai sarana penyelamatan.

Mengacu pula kepada hasil evaluasi berdasarkan Peraturan Menteri Pekerjaan Umun No.26 Tahun 2008 tentang "Persyaratan Teknis System Proteksi Kebakaran Pada Bangunan Gedung Dan Lingkungan" diperlukan perancangan ulang system proteksi kebakaran pada Gedung Serbaguna Tekmira ini. System proteksi kebakaran yang dirancang akan mengacu kepada Standar Nasional Indonesia (SNI) dan standar lain yang berkaitan dengan proteksi kebakaran gedung. Diharapkan dengan membuat perancangan system proteksi kebakaran yang sesuai dengan Standar Nasional Indonesia (SNI) dapat memberikan keamanan, keselamatan dan kenyamanan bagi para pengguna bangunan Gedung Serbaguna Tekmira ini.

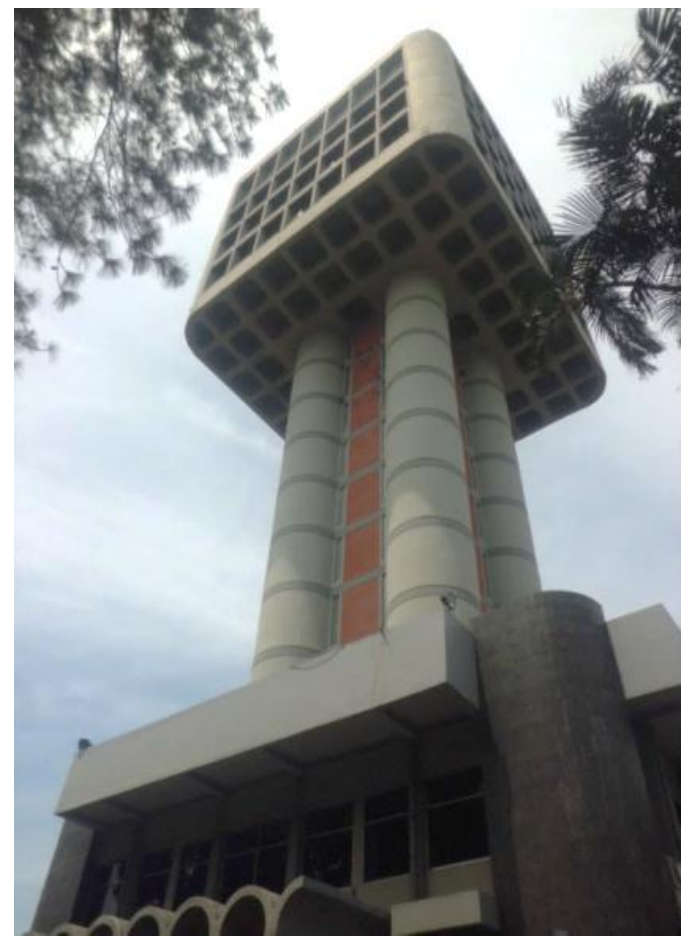

Gambar 1. Bangunan Gedung Serbaguna Tekmira 
Adapun tujuan dari penulisan ini adalah merancang dan mengevaluasi System Proteksi Kebakaran pada Gedung Serbaguna Tekmira di jalan Jendral Sudirman 623 Bandung sesuai dengan standar yang disyaratkan.

Ruang lingkup pembahasan dalam Perancangan System Proteksi Kebakaran pada Gedung Serbaguna Tekmira di jalan Jendral Sudirman 623 Bandung adalah sebagai berikut:

- Mengevaluasi existing dari sistem proteksi kebakaran yang sudah ada pada gedung Serbaguna Tekmira

- Merancang jalur evakuasi dan jalan keluar untuk sarana penyelamatan terhadap kebakaran

- Merancang penambahan tangga darurat sebagai jaluar evakuasi bila terjadi kebakaran

- Merancang system sprinkler, hydrant gedung dan detector kebakaran gedung.

- Menghitung kebutuhan kebutuhan air (ground watertank) berdasarkan kebutuhan debit air alat/system dan waktu penggunaannya.

- Menghitung rencana anggaran biaya dari perencanaana ulang System Proteksi Kebakaran pada Gedung Serbaguna Tekmira

\section{METODOLOGI}

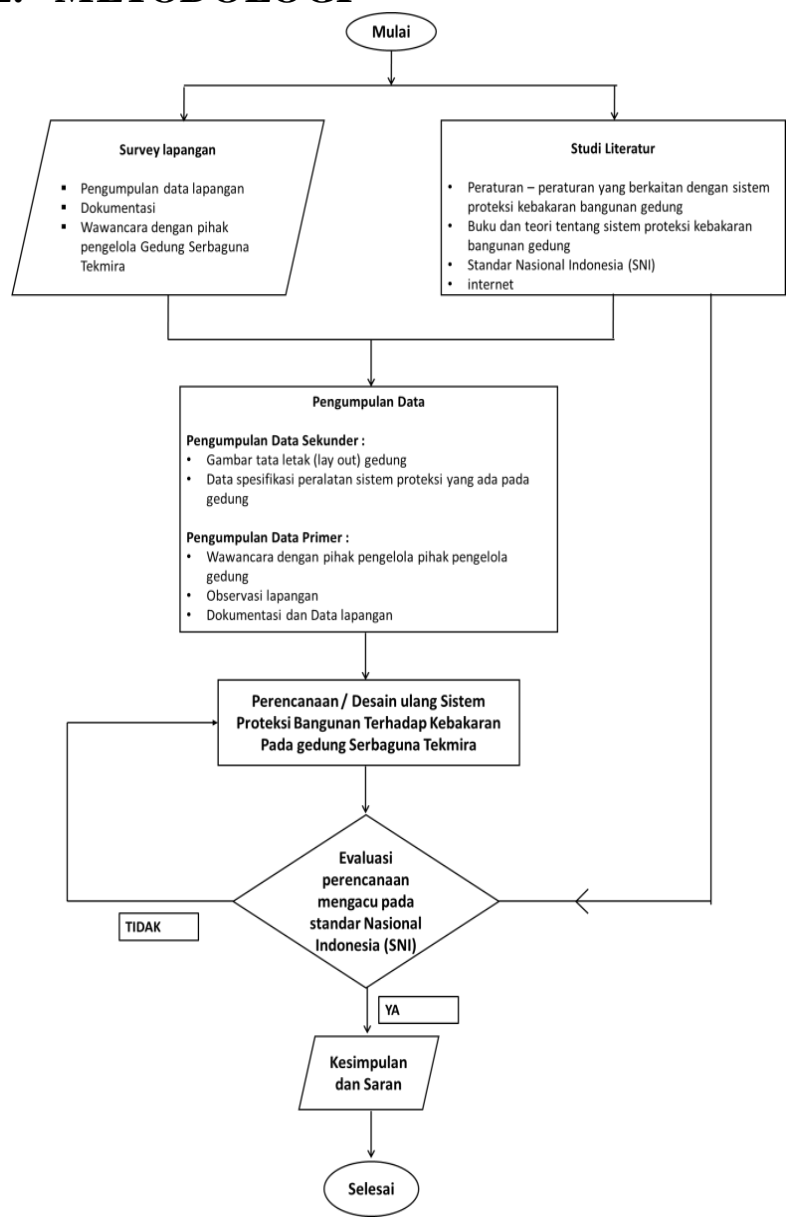

Metodologi ini dijelaskan tahapan-tahapan dalam melaksanakan kajian ini dimu lai dari pengumpulan data, pemahaman studi literatur, perancangan sistem proteksi kebakaran serta penarikan kesimpulan dari hasil perencanaan yang dibuat.

\section{PEMBAHASAN}

Evaluasi system proteksi kebakaran pada Gedung Serbaguna Tekmira ini mengacu kepada Undangundang No. 28 tahun 2002 tentang Bangunan Gedung atau lebih dikenal dengan UUBG 2002 menyebutkan bahwa persyaratan sebuah bangunan gedung harus menerapkan system proteksi terhadap kebakaran secara total, yang mencakup proteksi pasif, proteksi aktif dan membentuk manajemen keselamatan terhadap bahaya kebakaran. Berikut merupakan beberapa variable dari system proteksi kebakaran pada gedung Serbaguna Tekmira yang sudah di evaluasi berdasarkan standard dan persyaratan yang sudah ada:
1. Klasifikasi bangunan
2. Kelengkapan tapak
3. Sistem proteksi pasif dan
4. Sistem proteksi aktif

\section{Eksisting Gedung Serbaguna Tek mira}

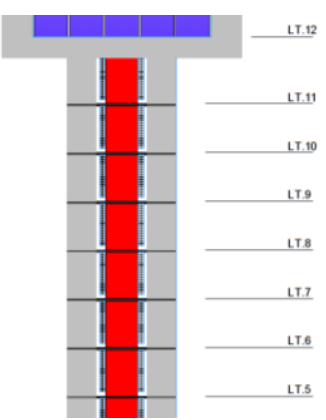

Gambar 3.Tampak depan Gedung Serbaguna Tekmira

Berdasarkan gambar 3 pada gedung Serbaguna Tekmira ini terdapat 16 lantai yang setiap lantainya dipergunakan sebagai berikut:

- Lantai 1: Gedung serbaguna dan Gedung SM Sair.

- Lantai 2: Ruangan staf bagian perawatan dan rumah tangga

- Lantai 3: Ruang Staf

- Lantai 4: Ruang Staf

- Lantai 5 s/d 8: Ruang Staf Divisi

- Lantai 9: Ruang Staf

- Lantai 10 s/d 11: Kantor dan gudang SmartFren

- Lantai 12 s/d 15: Ruangan staf-staf bagian Tekmira

- Lantai 16: Ruang Mesin Lift

Gambar 2.Flowchart Pelaksanaan Penelitian 


\section{Desain sistem proteksi kebakaran Gedung Serbaguna Tekmira}

Kesimpulan dari evaluasi system proteksi kebakaran pada bangunan gedung Serbaguna Tekmira yang mengacu kepada Undang-undang No. 28 tahun 2002 bangunan gedung Serbaguna Tekmira belum memenuhipersyaratan sepenuhnya. Sehingga untuk memenuhi persyaratan tersebut pada bangunan GedungSerbaguna Tekmira iniperlu perencanaan ulang desain system proteksi kebakaran, diantaranya adalah sebagai berikut:

1. Desain Sarana Penyelamatan Bangunan berupa jalur pe madam kebakaran.

2. Jalur evakuasi dalam gedung serta pembuatan rambu-rambu petunjuk arah evakuasi bila terjadi kebakaran.

3. Desain System Proteksi Kebakaran Pasif Gedung berupa penambambahan tangga kebakaran dan perencanaan perubahan posisi kamar mandi.

4. Desain System Proteksi Aktif Bangunan Gedung Serbaguna Tekmira seperti system sprinkler, hydrant gedung, Alat Pemadam Api Ringan (APAR), Alarm Kebakaran dan perhitungan kebutuhan air.

5. Pembuatan Shaft sebagai tempat menyimpan pipa-pipa kebutuhan air dan mechanical electrical gedung Serbaguna Tekmira

\section{Desain Jalur Pemadam Kebakaran}

Rencana desain jalur pemadam kebakaran gedung Serbaguna Tekmira di bagi menjadi 3 jalur pintu masuk pemadam kebakaran menuju gedung Serbaguna Tekmira saat terjadi kebakaran seperti terlihat pada gambar 3 .

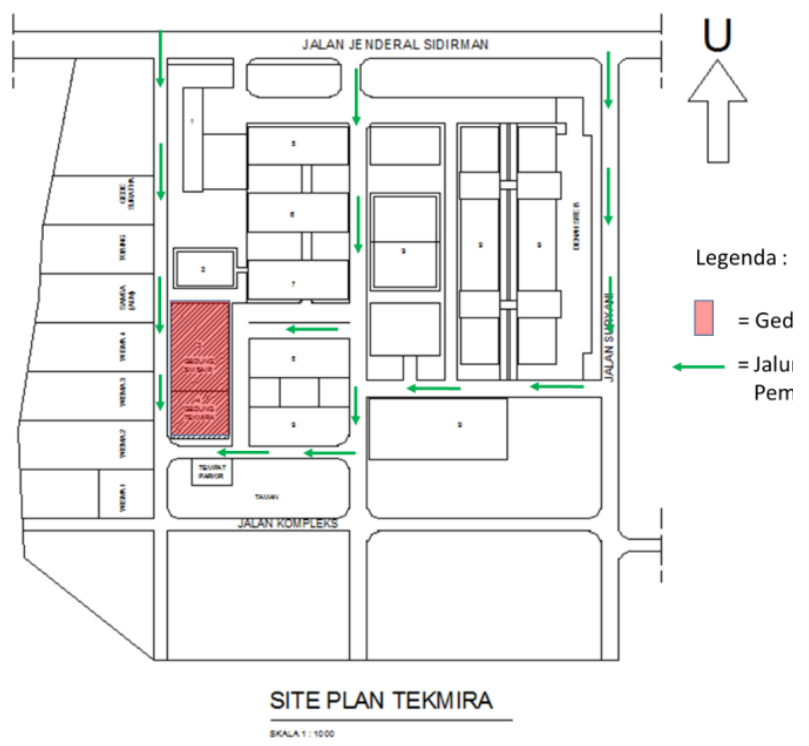

Gambar 4.A kses Jalur Pe madam Kebakaran Gedung Serbaguna Tekmira

\section{Desain Jalur Evakuasi Dalam Ge dung}

Desain jalur evakuasi Gedung Serbaguna Tekmira ini di desain berdasarkan posisi dan pengelompokan zona sebagai cara untuk mempermudah proses evakuasi. Selain itu pembuatan zona-zona arah evakuasi berfungsi untuk memperpendek jarak tempuh pengguna bangunan menuju jalur evakuasi pada saat terjadi kebekaran.
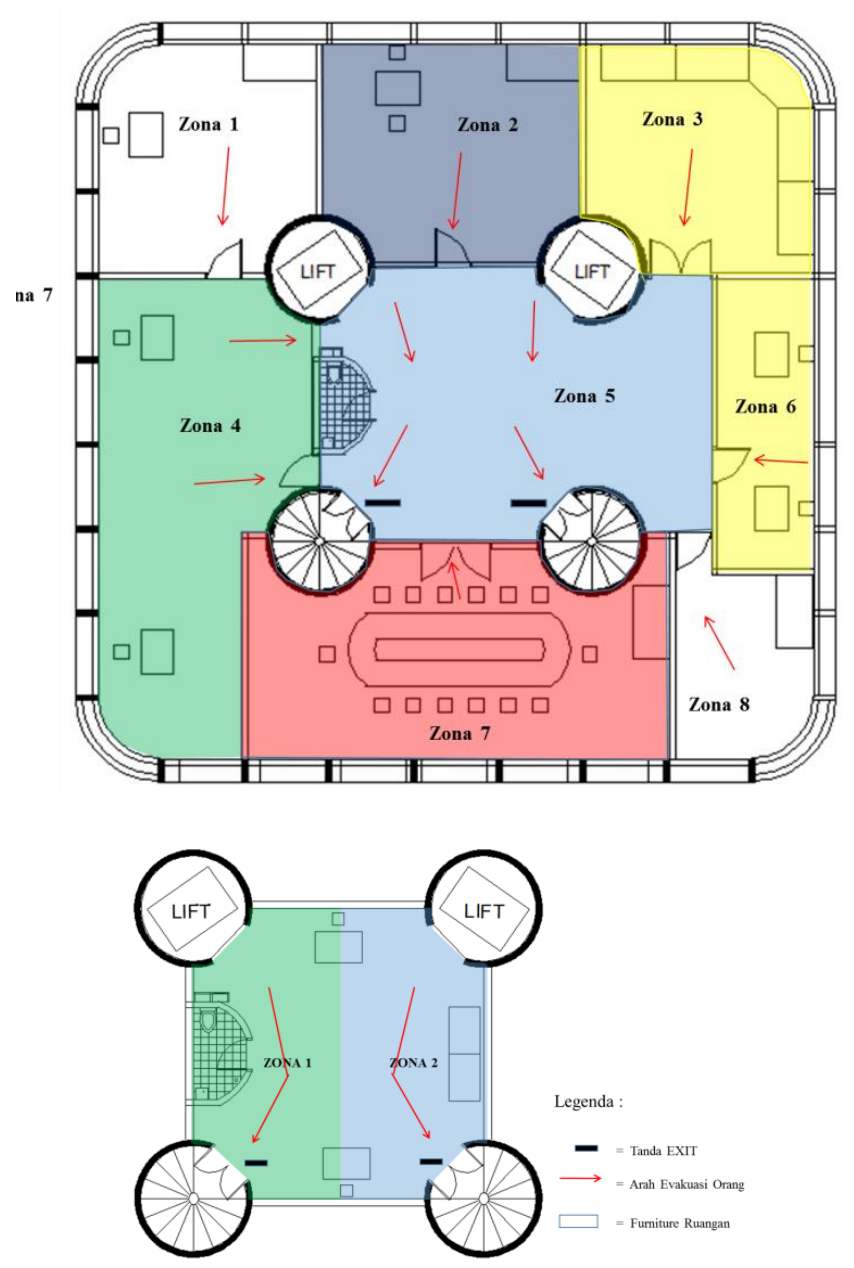

Gambar 5.Jalur Evakuasi Kebakaran dalam gedung

\section{Desain Tangga Darurat}

Desain tangga darurat yang akan dibuat, disamakan dengan tangga darurat eksisting yang telah di evalusi sebelumnya adalah sebagai berikut:

- Tangga darurat pada bangunan Gedung Serbaguna Tekmira terbuat dari baja yang memiliki ketahanan terhadap api selama 3 jam.

- Tangga Tekmira dipisahkan dari ruangan lain dengan dinding beton berbentuk melingkar (core wall) yang mempunyai ketahanan kebakaran selama 3 jam.

- Tebal dinding beton/ core wall nya adalah 15 $\mathrm{cm}$ 
- Lebar tangga Tekmira $120 \mathrm{~cm}$.

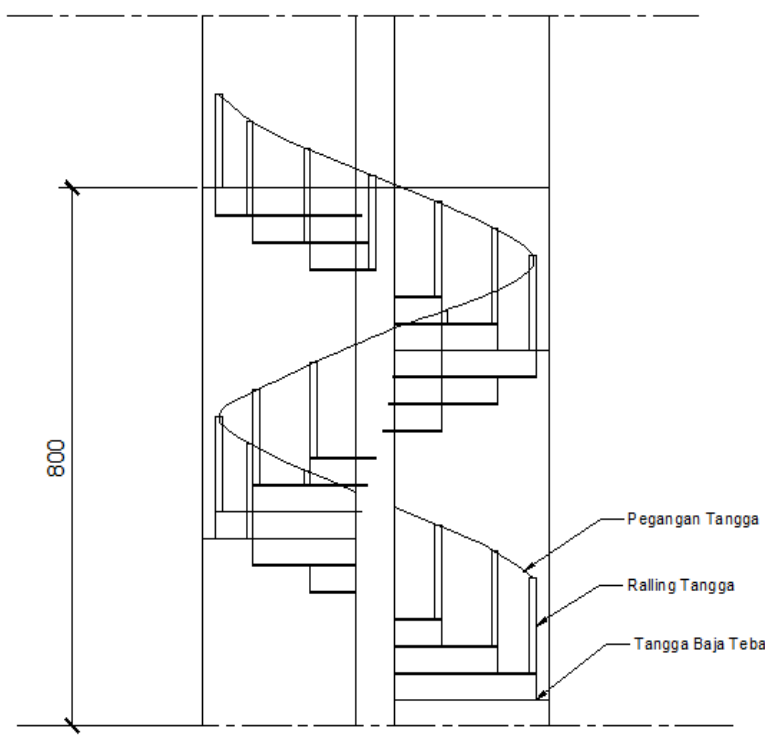

Gambar 6. Tangga Darurat Gedung Serbaguna Tekmira

\section{Desain System Proteksi Aktif}

Lingkup pembahasan system proteksi kebakaran aktif ini meliputi System sprinkler, hydrant, Alat pemadam api ringan (APAR) dan System alarm dan deteksi kebakaran (head detector \& smoke detector)

\section{Sistem Sprinkler}

Berikut perencanaan desain system sprinkler yang akan digunakan:

1. Sprinkler yang di pakai $1 / 2$ " dengan kapasitas $(\mathrm{Q})=25 \mathrm{GPM}=93,99$ liter $/$ men it

2. Kepadatan pancaran $=2,25 \mathrm{~mm} /$ menit $(\mathrm{SNI}$ 03-3989-2000)

3. Tekanan air $=2,2$ bar

4. Jarak maksimum antar titik sprinkler 3,7 meter

5. Jarak maksimum sprinkler dari dinidng tembok 1,7 meter

6. Arah pancaran ke bawah karena kepada sprinkler diletakan pada atap ruangan tipe pendent.

7. Kepakaan terhadap suhu, cairan dalam tabung gelas berwana jingga pada suhu $57^{\circ}$ $\mathrm{C}$

8. Daerah yang dilindungi adalah semua ruangan kecuali kamar mandi, toilet dan tangga yang diperkirakan tidak mempunyai potensi terjadinya kebakaran.

9. Sprin kler overlap adalah $1 / 4$ bagian

10. Diameter lubang sprinkler $=0,5$ inchi

11. Satu buah sprinkler mampu mencakup area sebesar $5 \mathrm{~m}$ x $5 \mathrm{~m}$.
Perhitungan untuk kebutuhan sprinker adalah sebagai berikut:

$$
\sum \text { Sprinkler }=\frac{\mathrm{L} \text { bangunan }}{25}=\ldots \text { unit }
$$

Tabel 1.Penerapan yang berkenaan dengan

\begin{tabular}{|c|c|c|}
\multicolumn{3}{c}{ pemas angan sprinkler } \\
\hline Lantai & Luas Bangunan & Perhitungan Kebutuhan \\
\hline 1 & $711,39 \mathrm{~m}^{2}$ & $\frac{711,39 \mathrm{~m} 2}{25}=28.45=28$ unit \\
\hline 2 & $287,03 \mathrm{~m}^{2}$ & $\frac{287,03 \mathrm{~m} 2}{25}=11,48=12$ unit \\
\hline 3 s/d 11 & $48,30 \mathrm{~m}^{2}$ & $\frac{48,30 \mathrm{~m} 2}{11,9}=1,93=2$ unit \\
\hline 12 s/d 15 & $380,25 \mathrm{~m}^{2}$ & $\frac{380,25 \mathrm{~m} 2}{11,9}=15,21=16$ unit \\
\hline
\end{tabular}

\begin{tabular}{|c|c|c|}
\hline NO. & LANTAI & $\begin{array}{c}\text { Jumlah } \\
\text { Sprinkler }\end{array}$ \\
\hline 1. & $\begin{array}{ll} & \text { Lantai 1: Gedung serbaguna dan } \\
& \text { Gedung SM Sair. } \\
\circ & \text { Lantai 2: Ruangan staf bagian } \\
\text { perawatan dan rumah tangga } \\
\circ \text { Lantai 3: Ruang staf } \\
\circ \text { Lantai 4: Ruang staf } \\
\circ \text { Lantai } 5 \mathrm{~s} / \mathrm{d} \text { 7: Ruang Staf Divisi } \\
\circ \text { Lantai } 8 \mathrm{~s} / \mathrm{d} \text { 10: Ruang Staf } \\
\circ \text { Lantai } 10 \mathrm{~s} / \mathrm{d} \text { 11: Kantor Smartfren } \\
\circ \text { Lantai } 12 \mathrm{~s} / \mathrm{d} \text { 15: Ruangan staf-staf } \\
\text { bagian tekmira } \\
\circ \text { Lantai } 16: \text { Ruang Mesin Lift }\end{array}$ & $\begin{array}{c}12 \\
2 \\
2 \\
2 \times 3 \\
2 \times 3 \\
2 \times 2 \\
16 \times 4 \\
2\end{array}$ \\
\hline & Jumlah & 126 \\
\hline
\end{tabular}

Berikut merupakan denah perencanaan penempatan titik-titik sprinkler:

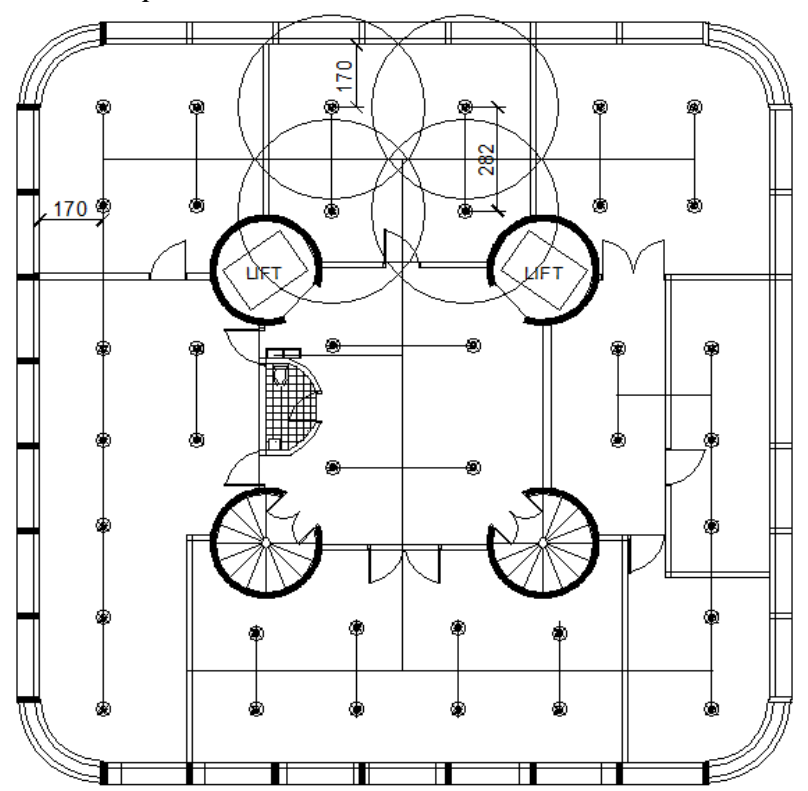




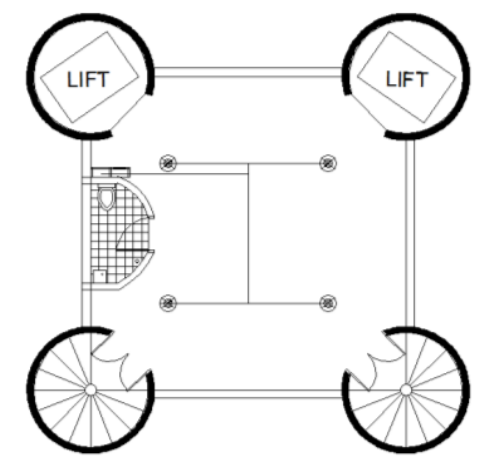

Gambar 7.Denah Penempatan Sprinkler

\section{Sis tem Hydrant}

Perencanaan system hiran gedung Serbaguna Tekmira ini berdasarkan pada SNI 03-1745-2000 dan National Fire Protection Assosiation (NFPA). Dimana spesifikasi hydrant gedung adalah sebagai berikut:

1. Jenis kebakaran ringan

2. Debit air sebesar 400 liter/menit

3. Tekanan air 6,9 bar

4. Hose nozzle 2,5 inchi $(30 \mathrm{~m})$

5. Aliran air minimal selama 30 menit.

Kebutuhan hydrant gedung dapat ditentukan oleh rumus empiris dibawah in $\mathrm{i}$ :

$$
\Sigma \text { Hydrant } \quad=\frac{\text { luas bangunan }}{800 \mathrm{~m} 2}=\ldots \text { unit }
$$

Tabel 2. Perhitungan yang berkenaan dengan pemasangan hydrant.

\begin{tabular}{|c|c|c|}
\hline Lantai & $\begin{array}{c}\text { Luas } \\
\text { Bangunan }\end{array}$ & Perhitungan Kebutuhan \\
\hline 1 & $711,39 \mathrm{~m}^{2}$ & $\frac{711,39 \mathrm{~m} 2}{800}=0,358=1$ unit \\
\hline 2 & $287,03 \mathrm{~m}^{2}$ & $\frac{287,03 \mathrm{~m} 2}{800}=0,86=1$ unit \\
\hline $3 \mathrm{~s} / \mathrm{d}$ & $48,30 \mathrm{~m}^{2}$ & $\frac{48,30 \mathrm{~m} 2}{800}=0,060=1$ unit \\
\hline 10,16 & & $\frac{380,25 \mathrm{~m} 2}{800}=0,478=1$ unit \\
\hline $12-15$ & $380,25 \mathrm{~m}^{2}$ & \\
\hline
\end{tabular}

Berdasarkan hasil perhitungan tabel diatas setiap lantai pada gedung Serbaguna Tekmira membutuhkan 1 unit hydrant gedung. Berikut perencanaan penempatan hydrant gedung:

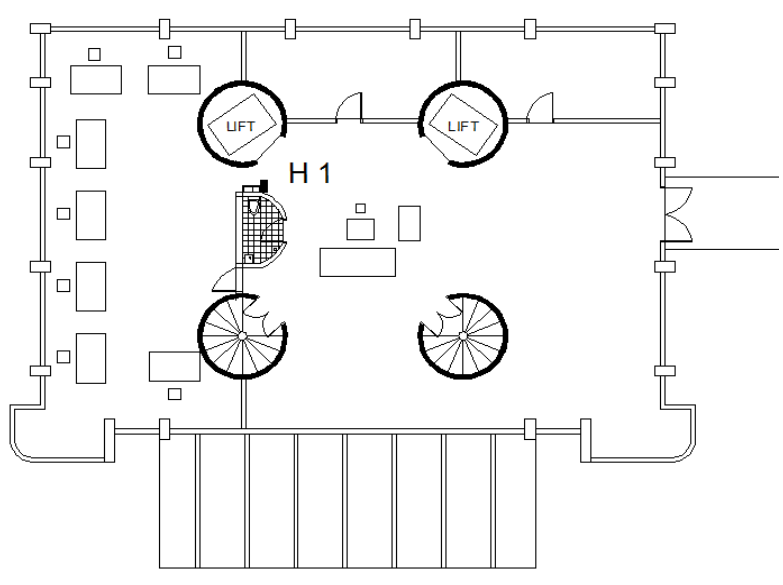

Gambar 8.Denah Penempatan Hydrant

$$
\text { H1 = Hydrant }
$$

\section{Alat Pemadam Api Ringan (APAR)}

Perhitungan kebutuhan APAR dengan syarat/kententuan yang tedapat pada Gedung Serbaguna Tekmira adalah sebagai berikut :

1. Jarak Penempatan maksimun adalah $20 \mathrm{~m}$, sedangkan pada masing-masing lantai dengan penempatan APAR > 1 buah jarak antar APAR nya $\leq 10$ meter.

2. Kebutuhan APAR dalam bangunan adalah sebagai berikut:

\section{$\frac{\text { Luas lantai }}{250 \mathrm{~m}^{2}} \times 1$ tabung}

3. Tabung yang dipergunakan min tabung $2 \mathrm{~kg}$.

Tabel 3. Perhitungan yang berkenaan dengan pemasangan APAR

\begin{tabular}{|c|c|c|}
\hline Lantai & Luas Bangunan & Perhitungan Kebutuhan \\
\hline 1 & $711,39 \mathrm{~m}^{2}$ & $\frac{711,39 \mathrm{~m} 2}{250 \mathrm{~m} 2}=2,845$ unit \\
\hline 2 & $287,03 \mathrm{~m}^{2}$ & $\frac{287,03 \mathrm{~m} 2}{250 \mathrm{~m} 2}=1,148$ unit \\
\hline $3 \mathrm{~s} / \mathrm{d} 10,16$ & $48,30 \mathrm{~m}^{2}$ & $\frac{48,30 \mathrm{~m} 2}{250 \mathrm{~m} 2}=0,193$ unit \\
\hline $11 \mathrm{~s} / \mathrm{d} 15$ & $380,25 \mathrm{~m}^{2}$ & $\frac{380,25 \mathrm{~m} 2}{250}=1,521$ unit \\
\hline
\end{tabular}




\begin{tabular}{|c|l|c|}
\hline NO. & \multicolumn{1}{|c|}{ LANTAI } & $\begin{array}{c}\text { Jumlah } \\
\text { APAR }\end{array}$ \\
\hline 1. & $\circ \begin{array}{l}\text { Lantai 1: Gedung serbaguna dan } \\
\text { Gedung SM Sair. }\end{array}$ & 3 \\
& $\circ \begin{array}{l}\text { Lantai 2: Ruangan staf bagian } \\
\text { perawatan dan rumah tangga }\end{array}$ & 2 \\
& $\circ$ Lantai 3: Ruang staf & 1 \\
& $\circ$ Lantai 4: Ruang staf & 1 \\
& $\circ$ Lantai 5 s/d 7: Ruang Staf Divisi & $1 \times 3$ \\
& $\circ$ Lantai 8 s/d 10: Ruang staf & $1 \times 3$ \\
& $\circ \quad$ Lantai 10 s/d 11: Kantor Smartfren & $1 \times 2$ \\
& $\circ \quad$ Lantai 12 s/d 15: Ruangan staf-staf & $2 \times 4$ \\
& bagian tekmira & 1 \\
\hline & Lantai 16: Ruang Mesin Lift & 24 \\
\hline \multirow{2}{|c|}{ Jumlah } & \\
\hline
\end{tabular}

Spesifikasi APAR yang dipergunakan pada bangunan Gedung Serbaguna Tekmira ini adalah APAR dengan kapasitas $5 \mathrm{~kg}$, waktu semprot 13 detik dengan tekanan kerja 15 bar. Jenis cairan nya adalah tepung basah.

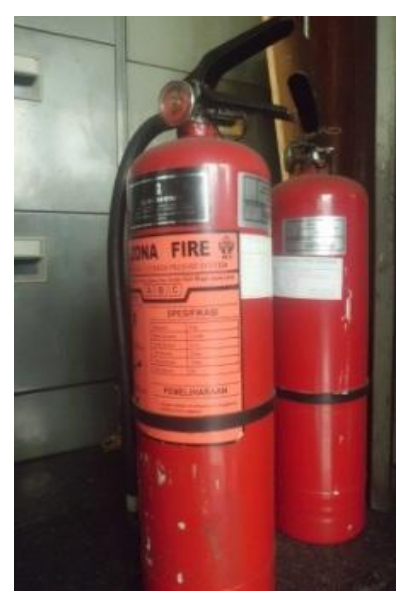

Gambar 9. APAR yang dipergunakan pada gedung Serbaguna Tekmira

\section{Alarm dan Detektor Kebakaran}

Perhitungan kebutuhan alarm dan detector kebakaran dapat dihitung dengan rumus empiris dibawah ini:

$\sum$ detector $=\frac{\mathrm{L} \text { bangunan }}{70}=\ldots$ unit
Tabel 4. Perhitungan yang berkenaan dengan pemasangan Alarm dan detektor

\begin{tabular}{|c|c|c|}
\hline Lantai & Luas Bangunan & Perhitungan Kebutuhan \\
\hline 1 & $711,39 \mathrm{~m}^{2}$ & $\frac{711,39 \mathrm{~m} 2}{70}=10,16$ unit \\
\hline 2 & $287,03 \mathrm{~m}^{2}$ & $\frac{287,03 \mathrm{~m} 2}{70}=4,10$ unit \\
\hline $3 \mathrm{~s} / \mathrm{d} 10,16$ & $48,30 \mathrm{~m}^{2}$ & $\frac{48,30 \mathrm{~m} 2}{70}=0,69$ unit \\
\hline $11 \mathrm{~s} / \mathrm{d} 15$ & $380,25 \mathrm{~m}^{2}$ & $\frac{380,25 \mathrm{~m} 2}{70}=5,43$ unit \\
\hline
\end{tabular}

\begin{tabular}{|c|c|c|}
\hline NO. & LANTAI & $\begin{array}{l}\text { Jumlah } \\
\text { APAR }\end{array}$ \\
\hline 1. & $\begin{array}{ll} & \text { Lantai 1: Gedung serbaguna dan } \\
& \text { Gedung SM Sair. } \\
\circ & \text { Lantai 2: Ruangan staf bagian } \\
& \text { perawatan dan rumah tangga } \\
\circ & \text { Lantai 3: Ruang staf } \\
\circ & \text { Lantai 4: Gudang } \\
\circ & \text { Lantai } 5 \text { s/d 7: Ruang Arsip } \\
\circ & \text { Lantai } 8 \text { s/d 10: Ruang Staf } \\
\circ & \text { Lantai } 10 \mathrm{~s} / \mathrm{d} 11: \text { Ruang Arsip } \\
\circ & \text { Lantai } 12 \mathrm{~s} / \mathrm{d} \text { 15: Ruangan staf-staf } \\
& \text { bagian tekmira } \\
\circ & \text { Lantai } 16: \text { Ruang Mesin Lift }\end{array}$ & $\begin{array}{c}1 \\
1 \\
1 \times 3 \\
1 \times 3 \\
1 \times 2 \\
6 \times 4\end{array}$ \\
\hline \multicolumn{2}{|r|}{ Jumlah } & 49 \\
\hline
\end{tabular}

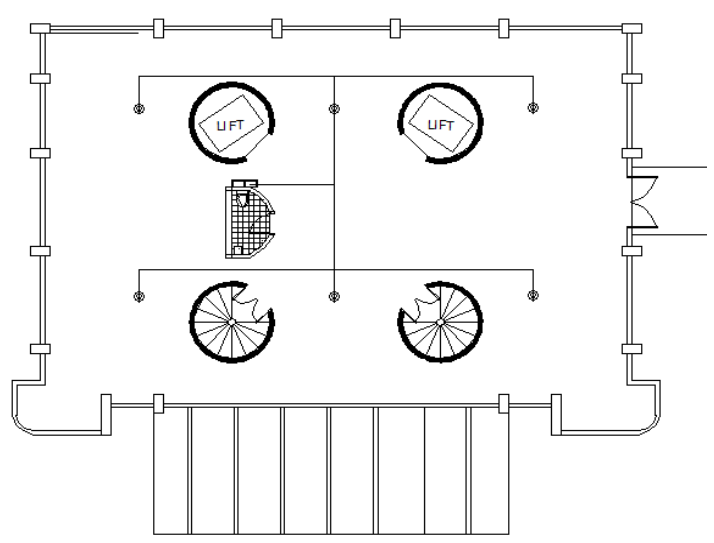

Gambar 10.Denah penempatan detektor kebakaran

Perencanaan detector kebakaran pada gedung Serbaguna Tekmira ini menggunakan detektor as ap (Smoke Detektor) 2 wire yang di integrasikan dengan alarm penanda kebakaran. 


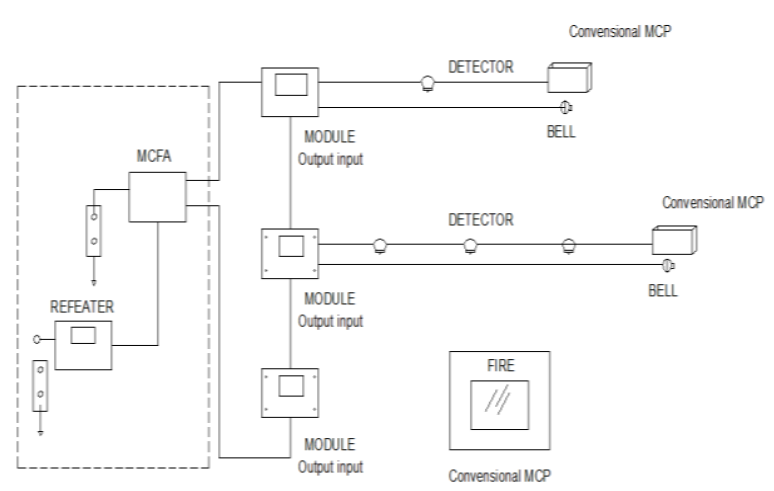

Gambar 11. Perencanaan sistem alarm dan detektor kebakaran

\section{Perhitung an Ground Watertank}

Dari hasil perhitungan sebelumnya mengenai total kebutuhan air setiap sistem yang sudah direncanakan adalah sebagai berikut:

- Total kebutuhan air bersih adalah $1,93 \mathrm{~m} 3$.

- Total kebutuhan air sistem sprinkler adalah $28,8 \mathrm{~m} 3$.

- Total kebutunan air sistem hidran gedung adalah 3,168 m3.

Perhitungan debit air total adalah sebagai berikut:

Kebituhan air (Q total)

$=$ kebutuhan air $+20 \%$ total kebutuhan

$=(\mathrm{Q}$ total $)+20 \%(\mathrm{Q}$ total $)$

Jadi total kebutuhan air

$=(1,93+33,07+3,168)+20 \%(\mathrm{Q}$ total $)$

$=38,168+(20 \% \times 38,168)$

$=45,801 \mathrm{~m} 3$.

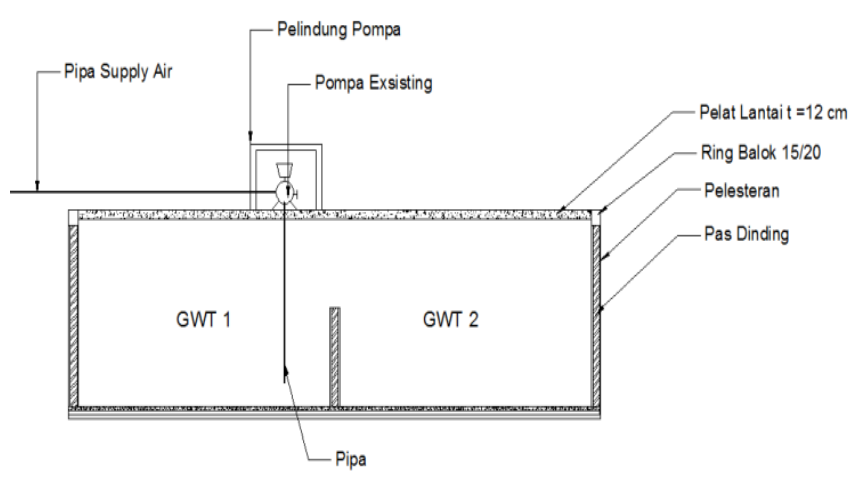

Gambar 11. Potongan Groundwatertank
Diketahui volume ground watertank pemanpungan air pada gedung Serbaguna Tekmira adalah sebagai berikut:

Volume Ground Watertank

$=(p \times l \times t) \times 2$ buah

$=(4 \mathrm{~m} \times 2,5 \mathrm{~m} \times 2,5 \mathrm{~m}) \times 2$ buah

$=50 \mathrm{~m} 3$.

$\underline{\text { Selisih Volume } \Delta \mathrm{V}}$

$\Delta \mathrm{V}=\mathrm{V}$ Ground Watertank $-\mathrm{V}$ kebutuhan

$=50 \mathrm{~m} 3-45,801 \mathrm{~m} 3$

$=4,198 \mathrm{~m} 3$

Jadi volume air pada Ground watertank sebagai tempat penampungan air gedung Serbaguna Tekmira sudah memenuhi dengan selisih sebesar 4,198 m3.

\section{Rencana Anggaran Biaya}

Perhitungan anggaran biaya perencanaan ulang system proteksi kebakaran pada gedung Serbaguna Tekmira ini dibagi menjadi 2 satuan pekerjaan yaitu perhitungan rencana anggaran system proteksi kebakaran aktif dan penambahan tangga kebakaran.Perencanaan anggaran biaya desain ulang system proteksi kebakaran pada gedung Serbaguna Tekmira, di dapat hasil sebagai berikut:

- Total rencana anggaran biaya system proteksi aktif = Rp. 793.437.440,-

- Total rencana anggaran biaya penambahan tangga darurat dan kelengkapannya sebesar Rp. 5.296.116.398,-

Maka total rencana anggaran biaya sebesar Rp. 6.089.553.838,

\section{KESIMPULAN DAN SARAN}

\subsection{Kesimpulan}

Hasil dari perencanaan ulang system proteksi kebakaran pada gedung Serbaguna Tekmira adalah sebagai berikut:

1. Jalur pemadam kebakaran menuju gedung Serbaguna Tekmira masuk melalui gerbang utama. Jalur dengan menggunakan perkerasan aspal dan me miliki lebar jalan > 5 meter.

2. Desain jalur evakusi dalam gedung Serbaguna Tekmira dibagi menjadi beberapa zona dan selanjutnya di arahkan ke pintu keluar (exit) untuk menuju ke titik ku mpul yang berada di luar bangunan.

3. Tangga darurat tambahan di desain memiliki spesifikasi sama dengan tangga eksisting yaitu tangga baja yang tahan api 
selama 3 jam dengan bentuk tangga melingkar diameter 2,5 meter.

4. Pembuatan kamar mandi sebagai pengganti kamar mandi eksisting. Desain kamar mandi kering dengan dilengkapi kloset dan wastafel.

5. Desain system sprinkler dengan jumlah 126 titik kepala sprinkler (pendent), jenis wet pipe system dengan tekanan 2,2 bar.

6. System hydrant gedung dengan tekanan 6,9 bar, terdapat satu buah hydrant pada setiap lantainya.

7. Alat pemadam api ringan (APAR) eksisting digunakan sebagai system proteksi aktif tambahan bila terjadi kebakaran. Menggunakan jenis tepung basah dengan kapasitas $5 \mathrm{~kg}$.

8. Alarm dan detector kebakaran semi otomatis karena dipadukan dengan system konvensional. Detector yang digunakan adalah jenis smoke detector yang diintegrasikan dengan Convensional MCP dan main control fire alarm (MCFA).

9. Persediaan ground watertank pada gedung Serbaguna Tekmira yang berkapasitas 50 m3 sudah memenuhi sehingga tidak perlu penambahan tangki penampungan. Selisih kebutuhan air dengan volume ground watertank sebesar 4,198 m3.

10. Total rencana anggaran biaya desain ulang system proeksi kebakaran gedung Serbaguna Tekmira adalah sebesar Rp. 6.089.553.838,-

\subsection{Saran}

Berdasarkan hasil laporan Penelitian yang telah disusun, maka penulis dapat memberikan beberapa saran sebagai berikut:

1. Manajemen penanggulangan bahaya kebakaran pada gedung Serbaguna Tekmira perlu di jalankan kembali. Serta seluruh elemen yang ada pada gedung Serbaguna Tekmira wajib untuk mentaati peraturan yang sudah di rancang demi kelancaran proses evakuasi saat terjadi kebakaran yang sesungguhnya.

2. Perencanaan dan desain yang dibuat dalam laporan ini merupakan standar umum yang bisa menjadi acuan pada saat pelaksanaan akan tetapi masih perlu di kaji u lang sebelum di aplikasikan. Selanjutnya perlu dibuat Standar Operasional Pemeliharaan seluruh komponen secara teknis untuk menyempurnakan keseluruhan System yang telah dibuat pada bangunan gedung Serbaguna Tekmira ini.

\section{DAFTAR PUSTAKA}

Juwana, Jimmy S Ir, MSAE (2005), "Panduan Sistem Bangunan Tinggi”. Jakarta, Penerbit Erlangga.

Keputusan Menteri Negara Pekerjaan Umum No.11 KPTS tahun 2000, tentang "Ketentuan Teknis Manajemen Penanggulangan Kebakaran di Perkotaan"

Keputusan Menteri Negara Pekerjaan Umum No.10 KPTS tahun 2000, tentang "Ketentuan Teknis Pengamanan Terhadap Bahaya Kebakaran Pada Bangunan Gedung Dan Lingkungan"

National Fire Protection Association. "Standar Portable Fire Extinguishers”. (NFPA 10)

Peraturan Menteri Pekerjaan Umum No.26 tahun 2008, tentang "Pasangan Konstruksi Tahan Api"Juwana, Jimmy S. 2005. mengenai "Panduan Sistem Bangunan Tinggi”, Jakarta: Erlangga

Pedoman Daerah. "Pedoman Pemeriksaan Keselamatan Bangunan Gedung”. (PD-T11-2005-C).

Standar Nasional Indonesia 03-1736-2000, tentang "Tata cara perencanaan sistem protekasi pasif untuk pencegahan bahaya kebakaran pada bangunan rumah dan gedung"

Standar Nasional Indonesia 03-1735 (2000), tentang "Tata Cara Perencanaan Akses Bangunan dan Akses Lingkungan Untuk Pencegahan Bahaya Kebakaran Pada Bangunan Gedung"

Standar Nasional Indonesia 03-1746 (2000), tentang "Tata cara perencanaan dan pemasangan sarana jalan keluar untuk penyelamatan terhadap bahaya kebakaran pada bangunan gedung"

Standar Nasional Indonesia 03-3985 (2000), tentang "Tata cara perencanaan, pemasangan dan pengujian sistem deteksi dan alarm kebakaran untuk pencegahan bahaya kebakaran pada bangunan gedung”

Standar Nasional Indonesia 03-3985-2000 tentang "Tata cara perencanaan, pemasangan dan pengujian sistem deteksi dan alarm kebakaran untuk pencegahan bahaya kebakaran pada bangunan gedung"

Standar Nasional Indonesia 03-3987-1995 tentang "Tata Cara Perencanaan Dan Pemasangan Pemadam Api Ringan Untuk Pencegahan Bahaya Kebakaran" 